\title{
POTENTIAL EXTRACT of PARE FRUIT (Momordica charantia) AGAINST DIFFERENTIAL LEUKOCYTE IN CARP (Cyprinus carpio) WHICH INFECTED WITH Aeromonas hydrophila
}

\author{
Sri Andayani ${ }^{1 *}$, Ellana Sanoesi ${ }^{1}$, Oktaviani Setya $^{1}$ \\ ${ }^{1}$ Aquaculture Study Program, Faculty of Fisheries and Marine Science, Brawijaya \\ University, Veteran St., Malang, Jawa Timur 65145, Indonesia.
}

*Correspondence :

ABSTRACT

yanik@ub.ac.id

Received : 2021-05-21

Accepted : 2021-06-23

Carp (C. carpio) in intensive production causes fish to be susceptible to disease, one of which is caused by $A$. hydrophila bacteria. Prevention is often done by giving synthetic chemical antibiotics that can be left in fish meat. Another alternative is to offer natural ingredients, one of which is bitter melon. The aim of the study was to determine

Keywords :

Aeromonas hydrophila, differential leukocytes, the effect of bitter melon extract (M.charantia) on differential leukocytes (lymphocytes, monocytes and neutrophils) in carp (C. carpio) infected with A. hydrophila goldfish, pare fruit extract. bacteria. This research method used a completely randomized design (CRD) with 4 treatments and 3 replications. The treatments used were the administration of different extract doses, namely: treatment A (550 ppm), treatment B (650 ppm), treatment $C(750 \mathrm{ppm})$, and treatment $D(850 \mathrm{ppm})$. positive $(\mathrm{K}+)$ with bacterial infection of 107 cells $/ \mathrm{ml}$ and administration of antibiotics chloramphenicol $0.03 \mathrm{mg} / \mathrm{L}$ and negative control (K-) with bacterial infection of 107 cells $/ \mathrm{ml}$. Blood collection when the fish are healthy, after offering the bitter gourd extract and after being infected. The results showed that bitter melon extract had a significantly different effect on leukocyte differential. The highest value obtained from treatment $D$ (850 ppm) with the percentage of lymphocytes (18.67-28)\%. neutrophils $(2.32=6.0) \%$ and monocytes $(21-26.67) \%$. In conclusion, treatment with $D$ dose of $850 \mathrm{ppm}$ used as an immunostimulant can increase the differential leukocytes.

\section{INTRODUCTION}

Goldfish is one of the freshwater fishery sector commodities that continues to grow from time to time. This fish is much liked by the public because the taste of the meat is delicious and the protein content is quite high. When viewed from the market aspect, the demand for carp tends to increase from year to year. In addition to the ever-increasing demand, from the business point of view, carp commodities provide sufficient business opportunities. The pattern of carp production that is carried out intensively provides many business options, namely hatchery business, nursery business, bank business and marketing. 
Journal of Fish Health Vol. 1 (1) - Juni 2021

Andayani et al. (2021)

https://doi.org/10.29303/jfh.v1i1.151

The pattern of carp production that is carried out intensively causes carp cultivation to be susceptible to disease. One of the causes of this disease is the bacterium A. hydrophila. The body size of this bacterium is very small, about 5 microns. This bacterium is very dangerous because it infects all parts of the fish body, both inside and outside the body (Harikrishnan et al. 2010)

Prevention that is often done by carp cultivators is found by giving synthetic chemical antibiotics. The use of synthetic antibiotics has now been limited because they can be left in fish meat, so other alternatives are needed to treat fish infected with the disease. An alternative that can be done is to offer antibiotics from natural ingredients. One of the natural ingredients that can be used as natural antibiotics is bitter melon which has properties as a blood sugar-lowering drug. In addition, bitter melon also has substances that function as antibacterial and anticancer. And materials that can increase fish immunity by observing differences in fish leukocytes (Monocytes, Neutrophils and lymphocytes (Suhermanto et al., 2011)

\section{METHODOLOGY}

Making bitter melon extract

The extraction method that will be used is the maceration method. The bitter gourd that will be used is in powder form. The fruit powder is obtained from Balai Batu Materia. Soaking (maceration) was carried out in a 1:4 ratio of 500 grams of bitter melon powder macerated using 2 liters of $70 \%$ ethanol. Left for 4 days in a closed macerator with stirring every day. After 4 days the macerate was filtered from the dregs using a Buchner funnel which had been lined with filter paper. The formed maserate was then soaked again using 1 liter of $70 \%$ ethanol for 2 days with the same method. The macerate formed was evaporated with a rotary evaporator at a temperature of $60 \mathrm{oC}$ and obtained a thick extract of 71.77 grams.

Treatment plan

The treatment design used RAL (completely randomized design) with 4 treatments and 3 replications. The administration of bitter melon fruit extract ( $M$. charantia) was carried out by soaking bitter melon (M. charantia) with doses of $A(550 \mathrm{ppm}), B(650 \mathrm{ppm}), C$ (750 ppm), and $D(850 \mathrm{ppm}) .2$ positive control as treatment of bacterial infection samples and administration of synthetic chemical antibiotics with a dose of $0.03 \mathrm{mg} / \mathrm{L}$, while negative control as sample treatment with infection with $A$. hydrophila bacteria and without administration of bitter melon fruit extract (M. charantia).

Research procedure

The study was conducted on a jar filled with 10 liters of water and added bitter melon according to a predetermined dose. Then the fish is put in the soaking water for 1 hour. After soaking for 1 hour, the fish were transferred to the maintenance media water. After 7 days, the fish were soaked again with bitter melon extract on day 8 in the same way as the first soaking for 1 hour. After that, the fish were infected with A. hydrophila bacteria with a bacterial density of 107 cells $/ \mathrm{ml}$, for 1 hour, then transferred to the maintenance media water and carried out.

Taking blood when the fish are healthy, after giving the bitter gourd extract and after being infected. Then the preparation of preparations is done by cleaning the glass object, then the fish blood is dripped on one end. Blood was smeared forward using another glass object at an angle of 450 . After the smear preparations were dry, the preparations were fixed with methanol for \pm 5 minutes. The preparations were stained with Giemsa dye. The preparations 
Journal of Fish Health Vol. 1 (1) - Juni 2021

Andayani et al. (2021)

https://doi.org/10.29303/jfh.v1i1.151

were then washed with water, dried and observed under a microscope (Bijanti, 2005).

RESULT

Lymphocytes

Based on observations made during maintenance, the average results obtained from lymphocyte observations are presented in Table 1.

Table 1. Mean Lymphocyte Carp (C. carpio)

\begin{tabular}{cccc}
\hline \multirow{2}{*}{ Treatment } & \multicolumn{3}{c}{ Mean \pm SD } \\
\cline { 2 - 4 } & Healthy fish & Post dipping extract & Post bacterial infection \\
\hline A & $18,67 \pm 0,6$ & $21,67 \pm 1,5$ & $24,00 \pm 1,0$ \\
B & $18,00 \pm 2,0$ & $23,33 \pm 0,6$ & $25,67 \pm 1,5$ \\
C & $18,33 \pm 1,2$ & $25,67 \pm 1,0$ & $28,33 \pm 0,6$ \\
D & $18,67 \pm 2,1$ & $28,00 \pm 1,0$ & $31,67 \pm 1,2$ \\
K+ & $17,33 \pm 2,1$ & $19,67 \pm 1,2$ & $20,67 \pm 1,5$ \\
K- & $18,00 \pm 1,0$ & $19,00 \pm 1,7$ & $20,00 \pm 1,0$ \\
\hline
\end{tabular}

\section{MONOSITE}

Based on Table 2. the mean monocytes of carp (C. carpio) showed an increase in monocytes.

Table 2. Average Monocyte Carp (C. carpio)

\begin{tabular}{cccc}
\hline \multirow{2}{*}{ Treatment } & \multicolumn{3}{c}{ Mean \pm SD } \\
\cline { 2 - 4 } & Healthy fish & Post dipping extract & Post bacterial infection \\
\hline A & $18,33 \pm 0,6$ & $18,67 \pm 2,1$ & $21,33 \pm 0,6$ \\
B & $17,00 \pm 2,6$ & $20,00 \pm 1,0$ & $24,00 \pm 1,0$ \\
C & $20,33 \pm 0,6$ & $23,00 \pm 1,0$ & $26,67 \pm 0,6$ \\
D & $21,00 \pm 1,0$ & $26,67 \pm 0,6$ & $29,33 \pm 2,1$ \\
K+ & $16,00 \pm 2,0$ & $17,00 \pm 2,0$ & $18,67 \pm 0,6$ \\
K- & $16,67 \pm 0,6$ & $16,33 \pm 0,6$ & $17,33 \pm 0,6$ \\
\hline
\end{tabular}

NEUTROPHIL

Based on observations made during maintenance, the average results obtained from neutrophil observations are presented in Table 3.

Table 3. Average Neutrophil Carp (C. carpio)

\begin{tabular}{cccc}
\hline \multirow{2}{*}{ Treatment } & \multicolumn{3}{c}{ Mean \pm SD } \\
\cline { 2 - 4 } & Healthy fish & Healthy fish & Healthy fish \\
\hline A & $1,00 \pm 1,7$ & $2,67 \pm 0,6$ & $3,00 \pm 1,0$ \\
B & $1,33 \pm 1,5$ & $3,33 \pm 0,6$ & $4,67 \pm 0,6$ \\
C & $2,33 \pm 0,6$ & $4,33 \pm 0,6$ & $6,67 \pm 1,2$ \\
D & $2,33 \pm 0,6$ & $6,00 \pm 1,0$ & $9,00 \pm 1,0$ \\
K+ & $1,33 \pm 1,2$ & $1,67 \pm 0,6$ & $2,33 \pm 0,6$ \\
K- & $2,00 \pm 1,0$ & $1,33 \pm 0,6$ & $1,67 \pm 0,6$ \\
\hline
\end{tabular}

\section{DISCUSSION}

Based on the results, the average lymphocyte count of carp (C. carpio) showed an increase in each treatment. This is in accordance with the statement of Rahma, et al. (2015), that the increase in lymphocytes is a reflection of the success of the fish immune system in developing a cellular (non-specific) immune response as a trigger for the immune response. 
Journal of Fish Health Vol. 1 (1) - Juni 2021

Andayani et al. (2021)

https://doi.org/10.29303/jfh.v1i1.151

Results The increase in monocytes is one of the responses of fish immunity to foreign objects that enter the fish body. According to Nurjannah, et al. (2013), that the number of monocytes in the white blood cell population is small. The number will increase if there are foreign substances in the tissues or circulation. According to Prakoso, 2012; Irianto et al. 2006) stated that the increase in the number of leukocytes was due to the components of leukocytes, namely heterophils (neutrophils) and monocytes which are part of leukocytes, which provide an immune response to bacteria.

Based on Table 3. The mean neutrophils of carp (C. carpio) showed an increase. The highest increase in neutrophils occurred in treatment $D(850 \mathrm{ppm})$. This increase in neutrophils was due to the response of the fish body to the presence of foreign objects that entered the fish body, namely in the form of treatment extracts and challenge test bacteria. This is in accordance with Andayani, et al. (2020), the main function of neutrophils is the destruction of foreign material through the process of phagocytosis, namely chemotaxis where cells will migrate towards particles, placing particles on cells, ingesting particles by cells and destroying particles by lysosomal enzymes in phagolysosomes. So that without stimulation from foreign objects in the form of bacteria, viruses or pathogens, neutrophils will not show an increased reaction. The content of saponins in bitter melon extract can stimulate an increase in neutrophils. According to Afifah, et al. 2014 ; Dianti et al. 2013), saponins perform inhibition by forming complex compounds with bacterial cell membranes through hydrogen bonds, so that they can destroy the permeability properties of bacterial cell membranes and ultimately lead to bacterial cell death, resulting in an increase in immunity.

\section{CONCLUSION}

Based on the results of the study, it was concluded that the administration of different doses of bitter melon extract (M. charantia) had an effect on the differential leukocytes of carp (C. caprio) which included lymphocytes, monocytes, neutrophils infected with $A$. hydrophila bacteria. The results showed the highest value of treatment $D(850 \mathrm{ppm})$ with a lymphocyte percentage of $(18.67-28) \%$. Neutrophils $(2.32=6.0) \%$ and monocytes $(21-26.67)$ $\%$, so that bitter melon fruit can be used as an immunostimulant that can increase the nonspecific immune response of carp.

\section{ACKNOWLEDGMENT}

Acknowledgments are addressed to the Head of the Cultivation Laboratory of the Faculty of Fisheries and Marine Sciences Universitas Brawijaya, Laboratory Assistant Titin Yuniastutik S.T.P. and sister Oktaviana Setya Abrina who helped during the research.

\section{REFERENCES}

Afifah, B., Abdulgani,N.\& Mahasri G. (2014). Efektifitas perendaman benih ikan mas (Cyprinus carpio L.) dalam larutan perasan daun api- api (Avicennia marina) terhadap penurunan jumlah Trichodina sp. Jurnal Sains dan Seni Pomits. 3(2), 2337-3520.

Andayani, S., Dadiono,M.S., Elwira, W.T \& Setiawan,F.H. 2020. Potency of aloe extract as immunostimulant for carp (Cyprinus carpio) aqains Aeromona salmonicida. Journal Biodiversitas, Vol 21(3) , 860-864.

Bijanti, R. (2005). Hematologi Ikan Teknik Pengambilan Darah dan Pemeriksaan Hematologi 
Journal of Fish Health Vol. 1 (1) - Juni 2021

Andayani et al. (2021)

https://doi.org/10.29303/jfh.v1i1.151

Ikan. Bagian IImu Kedokteran Dasar Veteriner. Fakultas Kedokteran Hewan. Universitas Airlangga. Surabaya.

Dianti, L., B. P. Slamet \& Restiana W. A. (2013). Ketahanan nonspesifik ikan mas (C. carpio) yang direndam ekstrak daun jeruju (Acanthus ilicifolius) terhadap infeksi bakteri Aeromonas hydrophila. Journal of Aquaculture Management and Technology. 2(4). 63-71.

Harikrishnan, R.,Balasundaramb,C. \& Soo Heo, M.S.(2010). Herbal supplementation diets on hematology and innate immunity in goldfish against Aeromonas hydrophila ). Fish \& Shellfish Immunology 28 (3),358-361

Irianto, A., Hernayanti \& Iriyanti (2006). Pengaruh suplementasi probiotik A3-51 terhadap derajat imunitas Oreochromis niloticus didasarkan pada angka kuman pada ginjal setelah uji tantang dengan Aeromonas hydrophila dan Aeromonas salmonicida achromogenes. Jurnal Perikanan. 8(2), 144-152.

Nurjannah, R. D. D., Slamet B. P, Sarjito \& Angela M.L.(2013). Pengaruh ekstrak daun sirsak (Annona muricata) terhadap profil darah dan kelulusanhidupan ikan mas (Cyprinus carpio) yang diinfeksi bakteri Aeromonas hydrophila. Journal of Aquaculture Management and Technology. 2(4), 72-83.

Prakoso, W. S. A. (2012). Gambaran jumlah dan hitung jenis sel leukosit darah ikan mas (Cyprinus carpio Linn) yang diterapi ekstrak daun sambiloto (Andrographis paniculata) setelah diinfeksi Aeromonas hydrophila. Artikel Ilmiah. Fakultas Kedokteran Hewan Airlangga. Surabaya.

Rahma, F. W., Gunanti M. \& Laksmi S. (2015). Pengaruh pemberian ekstrak Sargassum sp. dengan pelarut metanol pada pakan terhadap jumlah eritrosit dan diferensial leukosit ikan lele dumbo (Clarias gariepinus). Jurnal Ilmiah dan Kelautan. 7(2), 213-218.

Suhermanto, Andayani, S \& Maftuch. (2011). pemberian total fenol teripang pasir (Holothuria scabra) untuk meningkatkan leukosit dan diferensial leukosit ikan mas (Cyprinus carpio) yang Diinfeksi Bakteri Aeromonas Hydrophila. Jurnal Kelautan. 4(2), 49-56. 